\title{
基準品種を利用したデータ補完による北海道水稲の 発育予測モデルのパラメータ作成
}

\author{
濱菩孝弘 ${ }^{* \dagger} \cdot$ 三浦 周 ${ }^{* *} \cdot$ 藤倉潤治**. 根本 学* ·井上 聡* ·広田知良* \\ $\left(\begin{array}{ccl}* \text { 農研機構北海道農業研究センター } & \mp 062-8555 & \text { 北海道札幌市豊平区羊ヶ丘 } 1 \\ * * \text { 道総研農業研究本部上川農業試験場 } & \mp 078-0397 & \text { 北海道上川郡比布町南 } 1 \text { 線 } 5 \text { 号 }\end{array}\right)$
}

Parameter creation for a development prediction model of Hokkaido paddy rice by data supplementation using standard cultivars

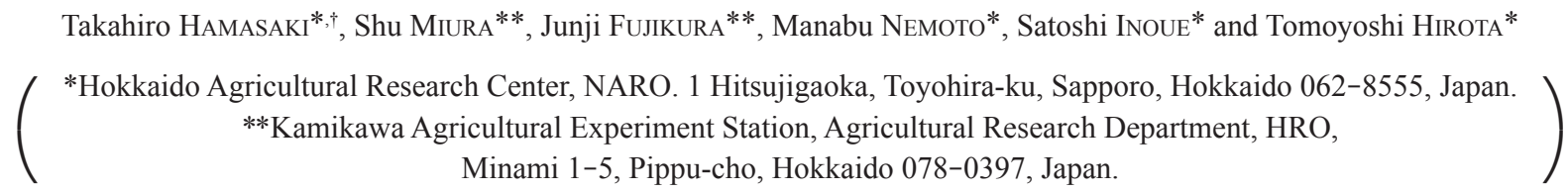

\begin{abstract}
Growth prediction models are used nationwide to support rice cultivation management and to predict/evaluate rice production. Development prediction models are also used in Hokkaido. The development index (DVI) model is easy to use and has a high prediction accuracy. However, DVI models are limited to 4 rice cultivars with an earliness of "early to medium". Therefore, we prepared the parameters of a DVI growth prediction model for rice cultivars with different levels of earliness for the Hokkaido region. During the preparation we encountered an issue because the development prediction model was not able to properly predict the difference in earliness between cultivars. This occurred due to a systematic estimation error, dependent upon the survey area of the growth data which was different between the cultivars. As a solution, we supplemented the growth data of the cultivars with the data of a "standard cultivar" to make the DVI model parameters. This was possible because the correlation between cultivars during the developmental stage of rice plants cultivated in Hokkaido is represented by a linear equation with a slope of almost 1 . With the DVI model created using supplemented data, it became possible to accurately predict the difference in earliness between cultivars. This method is effective for creating development prediction models for cultivars whose developmental data is limited to survey areas and new cultivars with little data available.
\end{abstract}

Key words: Data supplementation, Developmental index, DVI model, Hokkaido, Paddy rice キーワード：水稲, DVI, データ補完, 発育予測モデル, 北海道

\section{1. はじめに}

気象データに基づき水稲の出穂期や成熟期を予測する発 育予測モデルは，水稲の栽培管理，早期警戒情報の提供， 収量予測, 適地判定等, 様々に利用されている (Horie et al., 1995; Iizumi, 2007; 神田, 2007; 丹野ら, 2007)。北海道に おいては, 日平均・最高・最低気温, 日平均風速，日日照 時間から求めた簡易有効気温を積算する簡易有効積算温度 モデル（森田・村上, 1981; 村上ら, 1982; 竹川, 1991), お よび，日平均気温等から求める発育速度（DVR）を積算 した発育指数（DVI）を用いる DVI モデル (de Wit et al., 1970; 堀江・中川, 1990; 田中, 2007）が水稲の発育予測に 用いられている。

簡易有効積算温度モデルは，気温だけではなく日照時間 や風速を用いることにより近似的に水温の影響も考慮さ れており, 北海道内で広く用いられている。しかし, 竹 川（1991）による簡易有効気温を求める式は道南の限られ

2018 年 11 月 29 日 受付， 2019 年 1 月 28 日 受理

†Corresponding Author: hamasaki@affrc.go.jp

DOI: $10.2480 /$ cib.J-19-052
た地域での観測データに基づいて作成されている上，その 当時とは，測候所およびアメダスの日照時間観測に用いる 測器が，測定法の異なる測器に更新されている（気象庁, 2018）。旧日照計での観測值を新日照計での観測值に読み 替える換算式は提供されているが（気象庁, 2018), その逆 の換算式は提供されておらず，旧日照計での観測值に基づ き作成された簡易有効積算温度モデルを現在の日照計の值 を用いて使用することは基本的に困難である。

一方，日平均気温のみを用いたDVI モデルは，簡易有 効積算温度と比較して簡便で気象データも入手しやすく, また出穂期の推定精度はむしろ高いものの（広田・濱㟝, 2015), 現在引用が可能な形でパラメータが公表されてい る粳 (うるち) 米品種は「きらら 397」と「ほしのゆめ」,「な なつぼし」,「ゆめぴりか」（田中, 2007; 長田ら, 2013; 田中, 2016）の全て「やや早」であり，早生や晚生など早晚性の 異なる他の道内品種のモデルの作成が求められている。

そこで筆者らは現在栽培されている，道内の早晚性の 異なる粳米 9 品種について気温を用いたDVI モデルのパ ラメータセットの作成を試みた。パラメータ作成に際し, 使用するデー夕の取得地域に地域的な偏りがある品種や, 
表 1. 対象とした品種の早晚性とデータの取得場所および年次.

\begin{tabular}{|c|c|c|c|c|c|c|c|c|c|c|c|c|}
\hline \multirow{2}{*}{ 品種名 } & \multirow{2}{*}{ 早晚性 } & \multirow{2}{*}{ 調査種別* } & \multicolumn{7}{|c|}{ 調査場所**およびデータ数 } & \multirow{2}{*}{$\begin{array}{c}\text { デー夕数 } \\
\text { 合計 }\end{array}$} & \multirow{2}{*}{ 取得年次*** } & \multirow{2}{*}{$\begin{array}{l}\text { 奨決現地*** } \\
\text { デー夕数 }\end{array}$} \\
\hline & & & 北斗市 & 岩見沢市 & 比布町 & 訓子府町 & 滝川市 & 札幌市 & 石垣市 & & & \\
\hline \multirow{2}{*}{ 大地の星 } & \multirow{2}{*}{ 早 } & 定期作況 & - & - & - & - & - & 2 & 2 & 4 & $2012-2013$ & \multirow[b]{2}{*}{119} \\
\hline & & 奨決基本 & 17 & 34 & 34 & - & - & 28 & - & 113 & $1999-2015$ & \\
\hline \multirow{2}{*}{ ゆめぴりか } & \multirow{2}{*}{ やや早 } & 定期作況 & - & 7 & 8 & - & - & 5 & - & 20 & $2008-2015$ & \multirow{2}{*}{196} \\
\hline & & 奨決基本 & 16 & 19 & 18 & - & - & 20 & - & 73 & 2001-2014 & \\
\hline \multirow{2}{*}{ ほしのゆめ } & \multirow{2}{*}{ やや早 } & 定期作況 & 14 & 15 & 25 & - & - & - & - & 54 & $1996-2013$ & \multirow[b]{2}{*}{786} \\
\hline & & 奨決基本 & 42 & 42 & 43 & - & 12 & 38 & - & 177 & $1993-2015$ & \\
\hline \multirow{2}{*}{ おぼろづき } & \multirow{2}{*}{ やや早 } & 定期作況 & - & - & - & - & - & 6 & 2 & 8 & $2012-2015$ & \multirow{2}{*}{175} \\
\hline & & 奨決基本 & 18 & 26 & 28 & - & - & 30 & - & 102 & 2000-2014 & \\
\hline \multirow{2}{*}{ ななつぼし } & \multirow{2}{*}{ やや早 } & 定期作況 & 7 & 9 & 14 & - & - & 6 & 2 & 38 & $2002-2015$ & \multirow[b]{2}{*}{498} \\
\hline & & 奨決基本 & 34 & 36 & 36 & - & 2 & 33 & - & 141 & $1998-2015$ & \\
\hline \multirow{2}{*}{ きらら 397} & \multirow{2}{*}{ やや早 } & 定期作況 & 26 & 39 & 47 & - & - & 6 & 2 & 120 & $1989-2015$ & \multirow{2}{*}{1389} \\
\hline & & 奨決基本 & 59 & 61 & 62 & 18 & 28 & 42 & - & 270 & $1985-2015$ & \\
\hline \multirow{2}{*}{ きたあおば } & \multirow{2}{*}{ やや早 } & 定期作況 & - & - & - & - & - & 2 & 2 & 4 & 2012-2013 & \multirow{2}{*}{ - } \\
\hline & & 奨決基本 & - & - & - & - & - & 10 & - & 10 & $2006-2014$ & \\
\hline \multirow{2}{*}{ ふっくりんこ } & \multirow{2}{*}{ やや晚 } & 定期作況 & 15 & - & - & - & - & 6 & 2 & 23 & $2001-2015$ & \multirow{2}{*}{107} \\
\hline & & 奨決基本 & 30 & 26 & 6 & - & - & 12 & - & 74 & 1999-2013 & \\
\hline \multirow{2}{*}{ たちじょうぶ } & \multirow{2}{*}{ かなり晚 } & 定期作況 & - & - & - & - & - & 2 & 2 & 4 & $2012-2013$ & \\
\hline & & 奨決基本 & - & - & - & - & - & 6 & - & 6 & $2008-2014$ & - \\
\hline
\end{tabular}

*定期作況：定期作況調查（ただし，札幌と石垣は独自調查） 奨決基本：奨励品種決定基本調查

**北斗市: 道総研道南農業試験場, 岩見沢市: 道総研中央農業試験場, 比布市：道総研上川農業試験場（1993 年以前は旭川市） 訓子府町：道総研北見農業試験場，滝川市：道総研中央農業試験場，札幌市：農研機構北海道農業研究センター 石垣市：国際農業研究センター熱帯・島嶼研究拠点

***地点によって取得年次は異なる。. 全地点を合わせたデータの取得年の幅を示す。

**** 奨励品種決定現地調査

データ数自体が少ない品種は，それらデータに基づきパラ メータを作成すると発育予測モデルの推定精度が低い懸念 がある。そこで，道内の広い範囲でデータが取得されて おり，データの蓄積期間が長くデータ数が多い「きらら 397」を「基準品種」とし, 基準品種のデータを用いてパ ラメータ作成対象品種のデータを補完することで，モデル の推定精度の向上を図る方法を考案したので報告する。

\section{2. 材料および方法}

\section{1 使用データ}

対象とした水稲品種は, 北海道で現在栽培されている 9 品種である。早晚性の早いものから,「早」の「大地の星」, 「やや早」の「きらら 397」,「ほしのゆめ」,「ななつぼし」,「ゆ めぴりか」,「おぼろづき」,「きたあおば」,「やや晚」の「ふっ くりんこ」,「かなり晚」の「たちじょうぶ」の9品種である。 データの入手元は，1）地方独立行政法人北海道立総合 研究機構（道総研）の定期作況調査，2）奨励品種決定基 本調査，3）奨励品種決定現地調査，4）独自調査の 4 種 類あり，それぞれの調査地点は次の通りである：1）定期 作況調査: 道総研農業研究本部上川農業試験場（比布町, ただし 1993 年以前は旭川市), 中央農業試験場（岩見沢 市), 道南農業試験場 (北斗市), 2) 奨励品種決定基本調 査：上川農業試験場, 中央農業試験場 (岩見沢市, 滝川市), 道南農業試験場, 北見農業試験場（訓子府町), 国立研究 開発法人農業·食品産業技術総合研究機構 (農研機構) 北 海道農業研究センター (札幌市), 3) 奨励品種決定現地 調査: 今金町, 八雲町, 江差市, 七飯町, 知内町, 厚沢部町, 沼田町, 深川市, 妹背牛町, 芦別市, 新十津川町, 美唄市, 栗沢町, 栗山町, 由仁町, 長沼町, 南幌町, 石狩市, 当別町, 恵庭市, 共和町, 仁木町, 俱知安町, 蘭越町, 伊達市, 壮 瞥町, 武川町, 厚真町, 平取町, 新ひだか町, 遠別町, 羽

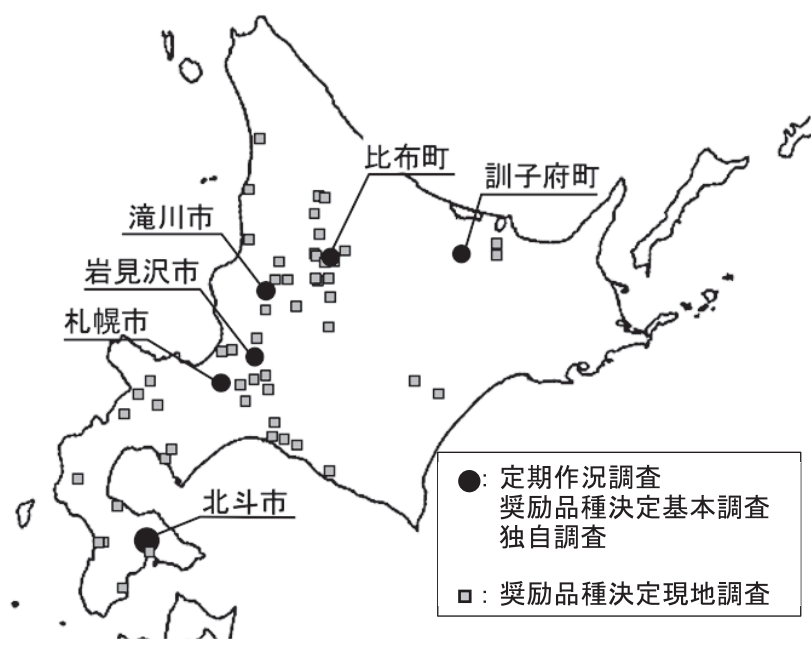

図 1. 北海道内のデー夕取得地点

このほか, 沖縄県石垣市 (独自調査) がある.

幌町, 小平町, 当麻町, 旭川市, 鷹栖町, 東川町, 愛別町, 和寒町，美瑛町，中富良野町，名寄市，士別市，池田町， 音更町, 美幌町, 女満別町の現地調査國場，4）独自調査: 北海道農業研究センターおよび国立研究開発法人国際農林 水産業研究センター熱帯・島嶼研究拠点 (沖縄県石垣市)。

表 1 に, 各品種の早晚性と定期作況調査, 奨励品種決定 基本調査, 独自調査のデータの調査地点ごとのデータ数・ デー夕取得期間, 奨励品種決定現地調査のデータ数を示す。 また図 1 に各地点の位置関係（北海道内のみ）を示す。各 データの調査項目（本研究で利用した項目のみ抜粋）は, 定期作況調査データと独自調査データでは移植日，苗の種 別 (中苗, 成苗), 移植時葉令, 幼穂形成期, 出穂期で, 奨励品種決定基本調査と奨励品種決定現地調査では移植 日，苗の種別（中苗，成苗)，出穂期である。北海道農業 
研究センターと国際農研熱帯・島嶼研究拠点で独自に取得 したデータは，表 1 では調査項目が同じ定期作況調査デー 夕の行に含めた。なお，独自調査の沖縄県石垣市のデー夕 は，北海道水稲への温暖化影響評価を目的に，現在の北海 道より栽培期間中の平均気温がおよそ $5{ }^{\circ} \mathrm{C}$ 高い条件下で栽 培・調査された（Nemoto et al., 2016）ものであり，本研究 ではモデルの適用温度範囲の高温側への拡大を目的として 加えた。

発育予測モデルで使用する日平均気温は, 農研機構より 提供されているメッシュ農業気象データ（大野ら, 2016） を用いた。

\section{2 使用した DVI モデル}

本論文では，堀江・中川（1990）の DVI モデルを基本に， 北海道内の水稲品種は日長感応性が無い, もしくは非常に 低い（細井, 1981; Ichitani et al., 1997）ことから，発育速度 （DVR）の算出には日長時間は用いず日平均気温のみを用 いる田中（2007）のモデルを用いた。

$$
\begin{aligned}
& D V I_{n}=D V I_{n-1}+D V R_{n} \\
& \text { ただし，幼穂形成期の } D V I=1 \text {, 出穂期は } 2 \\
& \text { 移植時の } D V I_{0}=B \cdot(N L t p) \\
& D V R_{n}=1 /\left(1+\exp \left(-A_{1} \cdot\left(T_{n}-T h_{1}\right)\right)\right) / G_{1} \quad\left(D V I_{n-1}<1\right) \\
& D V R_{n}=1 /\left(1+\exp \left(-A_{2} \cdot\left(T_{n}-T h_{2}\right)\right)\right) / G_{2} \quad\left(1 \leq D V I_{n-1}<2\right)
\end{aligned}
$$

ここで，添字の $n$ は基準となる日（ここでは移植日）か らの日数，NLtp は苗の葉令 (不完全葉を含まない)，Tは 日平均気温, $A, T h, G, B$ はパラメータで, 添字の 1 は 移植から幼穂形成期まで，2 は幼穂形成期から出穂期まで を示す。移植当日の DVI 初期值は苗の葉令から求められ, 日々のDVIは前日の DVIに当日のDVRを加えた值である。 発育ステージは移植日から幼穂形成期までと, 幼穂形成期 から出穂期の 2 つに分け, 幼穂形成期の DVI は 1, 出穂期 の DVIは 2 に設定し，それぞれの期間で別個のパラメー タを用いた。

\section{3 発育予測モデルのパラメータ決定法と作成したモデ ルの精度検証}

発育予測モデルのパラメータ作成には, 2.1 で示したデー 夕のうち, 幼穂形成期のある定期作況調査デー夕および独 自調査デー夕を用い，発育予測モデルの精度検証には奨励 品種決定基本調査データを用いた。

しかし，入手したデー夕は，品種によってはデー夕が 得られた地点が偏っており，またデー夕数も異なってい る（表 1)。「ふっくりんこ」は，定期作況調査が行われ たのは北斗市のみであり，逆に「ゆめぴりか」は北斗市 の定期作況調査データがない。「大地の星」「おぼろづき」 「きたあおば」「たちじょうぶ」は定期作況調査データがな く, パラメータ作成に用いるのは独自調査のデータのみと なり，デー夕数は 4 から 8 とごく少ない。そこで，最も データの蓄積期間が長く, 調査地点も偏りがない「きらら 397」を基準品種とし, 次の方法で他品種のデータを補完 した。

図 2 に，定期作況調査，奨励品種決定基本調査，奨励品
種決定現地調査，独自調査の全データを用いての「きらら 397」の出穂期に対する他各品種の出穂期の散布図を示す。 いずれの品種の出穂期も「きらら 397」の出穂期に対し, ピアソンの積率相関の $\mathrm{R}^{2}$ 值が 0.95 以上の高い相関を示し, かつ，傾きもほぼ1であり，少なくともグラフに表示さ れた範囲（年の通日（DOY）で 190〜240日）の出穂では, 基準品種との早晚の逆転はないと判断できる。幼穂形成期 も同様に $\mathrm{R}^{2}$ 值が 0.91 以上で (デー夕省略), 出穂期より は低い值となったが，これは調査が定期作況調査と独自調 査に限られ，デー夕数が少なかったためと推察され，幼穂 形成期を経て出穂に至ることを考えると，幼穂形成期も出 穂期と同程度の高い相関にあると考える。そこで，「きら ら 397」を基準品種とし, その幼穂形成期, 出穂期から, 上記相関に基づき作成した線形回帰式により，それ以外の 品種についても，「きらら 397」のデータと比較して調査 されていない全ての地点や年次の幼穂形成期, 出穂期を推 定し，データを補完した。この補完の結果，全ての品種の デー夕数は「きらら 397」と同じ 120 個となる。

デー夕補完の有無が発育予測モデルの推定精度におよぼ す影響を検討するため，補完せずに実測のデータのみを用 いた場合と，補完したデー夕を用いた場合の 2 通りで発 育予測モデルのパラメータ $A, B, T h, G$ を求めた。パラ メータの最適化は, Simplex 法 (Nelder and Mead, 1965) に よる最小二乗法にて行なった。なお， Simplex 法の計算に は，小林 (1981) が作成したプログラムの BASIC バージョ ンを Visual Basic for Applications 7.1 (Microsoft Corporation, Microsoft Excel for Mac 2016）に移植したものを使用した。

作成したパラメータセットによる出穂期の予測精度を, 奨励品種決定基本調査データを用いて検証した。その際, DVI の初期值の算出には移植時の葉令が必要であるが，奨 励品種決定調査デー夕には苗の種類（中苗，成苗）はある が葉令はないため, 定期作況調査データより苗の種類ごと の平均の葉令を求め, 移植時葉令は品種一律に中苗で 3.2 , 成苗で 4.1 とした。

\section{3. 結 果}

データ補完のない従来方式と，デー夕を補完する補完方 式の，品種ごとの出穂期の推定誤差を表 2 に示す。従来方 式では, 出穂期の推定誤差は RMSE で最大が「ふっくり んこ」の 3.6 日，最小が「きたあおば」の 1.7 日で，9品 種平均 2.8 日だったのに対し，補完方式では，最大が「大 地の星」の 3.3 日，最小が「たちじょうぶ」の 2.2 日の平 均 2.8 日で, 補完方式も従来方式と平均の推定精度は变わ らなかった。品種個別に見ると，「おぼろづき」と「ふっ くりんこ」では，補完方式により $0.7 〜 0.8$ 日推定誤差が 減少した一方，「ゆめぴりか」で 0.2 日，「きたあおば」で は 1.2 日, 推定誤差が増大した。検証用データ（奨励品種 決定基本調査）の調査地点別の推定誤差を表 3 に示す。上 記，補完方式で誤差が減少した「おぼろづき」は，岩見 沢市では従来方式と RMSE が変わらないものの, 比布町, 北斗市，札幌市では $0.9 \sim 1.2$ 日減少し，「ふっくりんこ」 は比布町では補完方式による RMSEの減少は 0.2 日と僅 かであるが，札幌市では 0.9 日，岩見沢市では 2 日以上， RMSEが減少した。一方，「ふっくりんこ」は北斗市では 

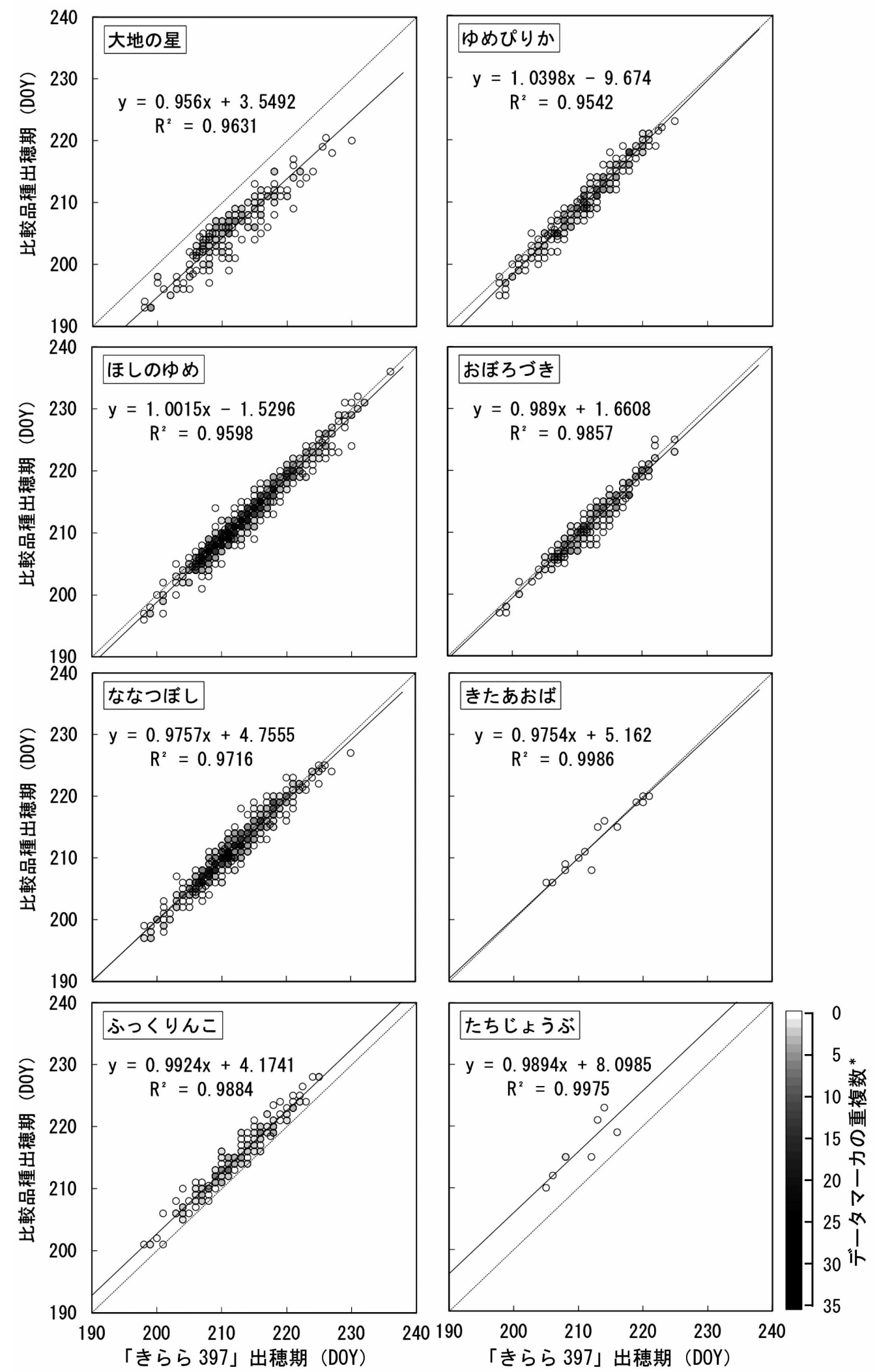

図 2. 各品種と「きらら 397」との出穂期の相関 *マーカーの色の濃さはデータプロットの重なりを示す。

RMSE が 0.7 日増大した。補完方式により誤差が増大した 「ゆめぴりか」は，岩見沢市でRMSE が 0.4 日減少してい るものの，比布町で 0.7 日，北斗市で 0.4 日，札幌で 0.2 日増大した。「きたあおば」は，検証用のデータが札幌市 での奨励品種決定現地調査データのみであり, 上記 RMSE
の 1.2 日の増大は札幌市での值である。

品種の早晚性が正しく推定されているかについて, 各品 種の出穂期と「きらら 397」の出穂期との差の平均值を早 晚性の指標とみなし，その実測值，従来方式による発育予 測モデルでの推定值，補完方式による発育予測モデルでの 
推定值を表 4 に示す。従来方式で作成した発育予測モデル では，すべての品種について「きらら 397」を基準とする と出穂を実測值より早めに推定しているとともに，早晚の 順位が実測值と異なる結果となった。特に,「ふっくりんこ」 は実測值よりも 3.2 日，早く推定され，実際には「やや早」 の「きらら 397」よりも2 階級晚生の「やや晚」であるに も関わらず，「きらら 397」よりも早く出穂すると推定さ れた。また，「きたあおば」と「きらら 397」との間，および， 「おぼろづき」と「ななつぼし」との間の順位も逆転して いた。一方，補完方式により，全体的に実測值より早めの 傾向は残るものの, 品種の早晚の順位は実測と同じとなり, 「ふっくりんこ」の出穂期推定值の平均值は「きらら 397」

表 2. 従来方式と補完方式によりパラメー夕を求めた発育予測モ デルの各品種の出穂期推定誤差の比較.

\begin{tabular}{ccccc}
\hline & \multicolumn{4}{c}{ 移植期からの出穂期推定精度 } \\
\cline { 2 - 5 } & $\begin{array}{c}\text { 検証用 } \\
\text { デー夕数 }\end{array}$ & 推定誤差 & (RMSE $($ 日) $)$ & RMSE 差 \\
\cline { 3 - 5 } & 従来方式 & 補完方式 & 従来-補完 \\
\hline 大地の星 & 113 & 3.4 & 3.3 & 0.1 \\
ゆめびりか & 73 & 2.6 & 2.8 & -0.2 \\
ほしのゆめ & 177 & 3.1 & 3.0 & 0.1 \\
おぼろづき & 102 & 3.1 & 2.4 & 0.7 \\
ななつぼ & 141 & 2.6 & 2.6 & 0.0 \\
きらら397* & 270 & 3.2 & $(3.2)$ & $(0.0)$ \\
きたあおば & 10 & 1.7 & 2.9 & -1.2 \\
ふっくりんこ & 74 & 3.6 & 2.8 & 0.8 \\
たちじょうぶ & 6 & 2.3 & 2.2 & 0.1 \\
\hline た平均 & & 2.8 & 2.8 & 0.0 \\
\hline
\end{tabular}

*基準品種のため, 補完方式も従来方式と同じ值となる.
より 1.9 日遅く，実測との差は 0.7 日まで減少した。

\section{4. 考察}

従来方式でパラメー夕を作成した発育予測モデルによる 出穂期の推定で見られた「きたあおば」と「きらら 397」 との早晚の逆転，「おぼろづき」と「ななつぼし」との早 晚の逆転は, 同じ「やや早」内でのわずかな差の逆転であり, 実際の栽培でも起こりうる現象であろう。一方，「きら ら 397」と「ふっくりんこ」の出穂期の逆転は，早晚性 「やや早」と「やや晚」の 2 階級の違いに渡るものであり, 栽培管理や作況等の把握・予測に利用するにあたり, 品種 の特性上ほぼあり得ない「逆転」した予測結果をもたらす

表 3. 地域別出穂期推定誤差（RMSE (日)).

\begin{tabular}{|c|c|c|c|c|c|c|c|}
\hline & & 比布町 & 岩見沢市 & 北斗市 & 訓子府町 & 滝川市 & 札幌市 \\
\hline 大地の星 & $\begin{array}{c}\text { 従来方式 } \\
\text { 補完方式 } \\
\mathrm{N}^{*}\end{array}$ & $\begin{array}{l}2.3 \\
2.1 \\
34\end{array}$ & $\begin{array}{l}4.3 \\
3.9 \\
34\end{array}$ & $\begin{array}{c}3.4 \\
3.9 \\
17\end{array}$ & $\begin{array}{l}- \\
- \\
-\end{array}$ & $\begin{array}{l}- \\
- \\
-\end{array}$ & $\begin{array}{l}3.1 \\
3.5 \\
28\end{array}$ \\
\hline ゆめぴりか & $\begin{array}{c}\text { 従来方式 } \\
\text { 補完方式 } \\
\text { N }\end{array}$ & $\begin{array}{l}1.6 \\
2.3 \\
18\end{array}$ & $\begin{array}{l}2.8 \\
2.4 \\
19\end{array}$ & $\begin{array}{l}3.7 \\
4.1 \\
16\end{array}$ & $\begin{array}{l}- \\
-\end{array}$ & $\begin{array}{l}- \\
-\end{array}$ & $\begin{array}{l}2.0 \\
2.2 \\
20\end{array}$ \\
\hline ほしのゆめ & $\begin{array}{c}\text { 従来方式 } \\
\text { 補完方式 } \\
\text { N }\end{array}$ & $\begin{array}{l}1.5 \\
1.6 \\
43\end{array}$ & $\begin{array}{l}4.7 \\
4.1 \\
42\end{array}$ & $\begin{array}{l}2.6 \\
2.9 \\
42\end{array}$ & $\begin{array}{l}- \\
- \\
-\end{array}$ & $\begin{array}{c}4.1 \\
3.6 \\
12\end{array}$ & $\begin{array}{l}2.4 \\
2.4 \\
38\end{array}$ \\
\hline おぼろづき & $\begin{array}{c}\text { 従来方式 } \\
\text { 補完方式 } \\
\text { N }\end{array}$ & $\begin{array}{l}2.6 \\
1.7 \\
28\end{array}$ & $\begin{array}{l}3.2 \\
3.2 \\
26\end{array}$ & $\begin{array}{l}3.5 \\
2.3 \\
18\end{array}$ & $\begin{array}{l}- \\
- \\
-\end{array}$ & $\begin{array}{l}- \\
-\end{array}$ & $\begin{array}{l}3.3 \\
2.2 \\
30\end{array}$ \\
\hline ななつぼし & $\begin{array}{c}\text { 従来方式 } \\
\text { 補完方式 } \\
\text { N }\end{array}$ & $\begin{array}{l}1.5 \\
1.6 \\
36\end{array}$ & $\begin{array}{l}3.8 \\
3.3 \\
36\end{array}$ & $\begin{array}{l}2.8 \\
3.3 \\
34\end{array}$ & $\begin{array}{l}- \\
- \\
-\end{array}$ & $\begin{array}{c}0.7 \\
1.6 \\
2\end{array}$ & $\begin{array}{l}1.6 \\
1.7 \\
33\end{array}$ \\
\hline きらら 397 & $\begin{array}{c}\text { (従来方式) } \\
\mathrm{N}\end{array}$ & $\begin{array}{l}2.4 \\
62\end{array}$ & $\begin{array}{c}3.0 \\
61\end{array}$ & $\begin{array}{l}3.1 \\
59\end{array}$ & $\begin{array}{l}1.7 \\
18\end{array}$ & $\begin{array}{l}1.6 \\
28\end{array}$ & $\begin{array}{l}2.1 \\
42\end{array}$ \\
\hline きたあおば & $\begin{array}{c}\text { 従来方式 } \\
\text { 補完方式 } \\
\text { N }\end{array}$ & $\begin{array}{l}- \\
- \\
-\end{array}$ & $\begin{array}{l}- \\
- \\
-\end{array}$ & $\begin{array}{l}- \\
- \\
-\end{array}$ & $\begin{array}{l}- \\
- \\
-\end{array}$ & $\begin{array}{l}- \\
- \\
-\end{array}$ & $\begin{array}{c}1.7 \\
2.9 \\
10\end{array}$ \\
\hline ふっくりんこ & $\begin{array}{c}\text { 従来方式 } \\
\text { 補完方式 } \\
\text { N }\end{array}$ & $\begin{array}{c}2.4 \\
2.2 \\
6\end{array}$ & $\begin{array}{l}5.1 \\
3.0 \\
26\end{array}$ & $\begin{array}{l}2.4 \\
3.1 \\
30\end{array}$ & $\begin{array}{l}- \\
- \\
-\end{array}$ & $\begin{array}{l}- \\
- \\
-\end{array}$ & $\begin{array}{l}2.3 \\
1.4 \\
12\end{array}$ \\
\hline たちじょうぶ & $\begin{array}{c}\text { 従来方式 } \\
\text { 補完方式 } \\
\mathrm{N}\end{array}$ & $\begin{array}{l}- \\
- \\
-\end{array}$ & $\begin{array}{l}- \\
-\end{array}$ & $\begin{array}{l}- \\
- \\
-\end{array}$ & $\begin{array}{l}- \\
- \\
-\end{array}$ & $\begin{array}{l}- \\
-\end{array}$ & $\begin{array}{c}2.3 \\
2.2 \\
6\end{array}$ \\
\hline
\end{tabular}

*N : データ個数

表 4. 各品種の出穂期実測值と推定値それぞれの「きらら 397」 との差と早晚の順位.

\begin{tabular}{|c|c|c|c|c|c|c|}
\hline \multirow{3}{*}{ 品種 } & \multicolumn{6}{|c|}{$\begin{array}{c}\text { きらら } 397 \text { との出穂期の差の平均（日）* } \\
\text { および早晚の順位（括弧内） }\end{array}$} \\
\hline & \multirow{2}{*}{\multicolumn{2}{|c|}{ 実測值 }} & \multicolumn{4}{|c|}{ 推定值 } \\
\hline & & & \multicolumn{2}{|c|}{ 従来方式 } & \multicolumn{2}{|c|}{ 補完方式 } \\
\hline 大地の星 & -5.3 & (1) & -6.7 & (1) & -6.1 & (1) \\
\hline ゆめぴりか & -1.7 & (2) & -2.7 & (2) & -2.0 & (2) \\
\hline ほしのゆめ & -1.0 & (3) & -2.5 & (3) & -1.9 & (3) \\
\hline おぼろづき & -0.9 & (4) & -1.2 & (5) & -1.6 & (4) \\
\hline ななつぼし & -0.5 & (5) & -2.1 & (4) & -1.0 & (5) \\
\hline (きらら 397 & 0 & (6) & 0 & (8) & 0 & (6) ) \\
\hline きたあおば & 0.4 & (7) & -1.1 & (6) & 0.2 & (7) \\
\hline ふっくりんこ & 2.6 & (8) & -0.6 & (7) & 1.9 & (8) \\
\hline たちじょうぶ & 6.1 & (9) & 3.9 & (9) & 5.6 & (9) \\
\hline
\end{tabular}

*対象品種の出穂期-「きらら 397」の出穂期 
発育予測モデルは，実用上受け入れがたい。発育予測モデ ルの推定精度が，モデルの作成に使うデータに依存するこ とは従来指摘されており，モデルの安定性向上・広域適応 性の確保には広範な地域でのデー夕取得が望ましいとされ る（堀江 · 中川, 1990; 中川 · 堀江, 1995; 中野ら, 2015)。今 回，発育予測モデルパラメータ作成に用いたデータは，品 種によっては調査地点や年数（データ個数）がごく限られ ており（表 1)，それが品種間の早晚の逆転を生じた原因 の可能性がある。

今回基準品種とした「きらら 397」の出穂期について, パラメータの作成に使ったデータの調査地点別に, 推定值 と実測值との関係を図 3 に示す（道内のみ; 定期作況調査 と奨励品種決定基本調査デー夕を合わせて示す)。実測值 に対して北斗市では出穂が遅めに推定され, 比布町と札幌 市はやや遅め〜同程度, 岩見沢市では逆に早めに推定され, 調査地点に依存する系統誤差が認められた。「きらら 397」 以外の品種についても, 従来方式でのモデルで推定した出 穂期の, 実測值からの偏差を調査地点ごとに平均して表 5 に示すとともに, さらに調査地点間の系統誤差の違いをよ

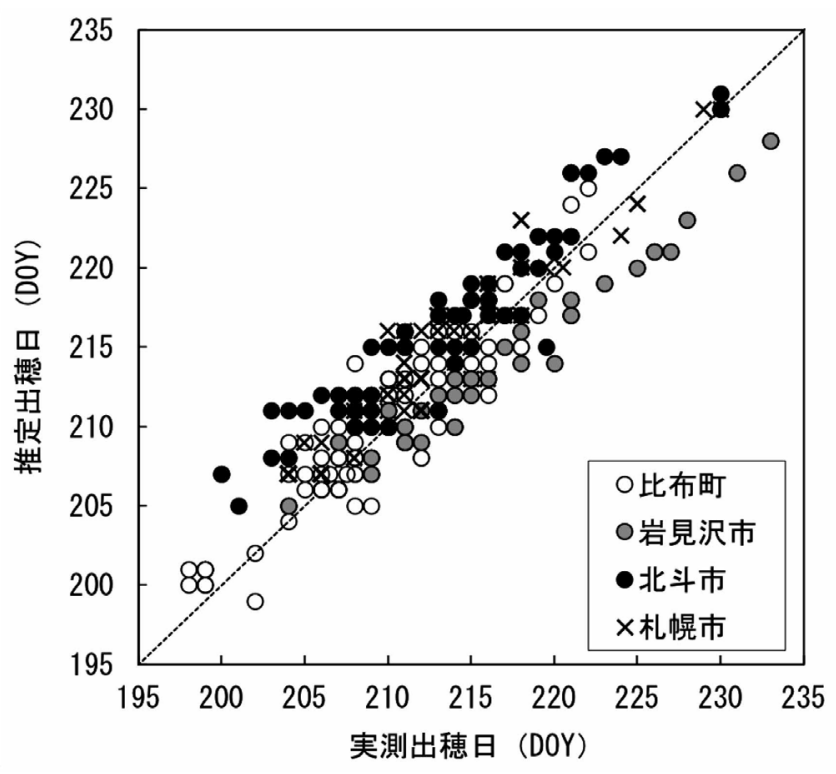

図 3. 地域別「きらら 397」出穂期推定値と実測値との関係 石垣市のデータは, 栽培時期が他地点と半年ずれているため 割愛した.

表 5. 調查地点に依存した出穂期推定值の系統誤差.

\begin{tabular}{|c|c|c|c|c|}
\hline \multirow{2}{*}{ 品種 } & \multicolumn{4}{|c|}{ 出穂期推定值の偏差 * 平均值 $\pm \mathrm{SE}$ (日) } \\
\hline & 比布町 & 岩見沢市 & 北斗市 & 札幌市 \\
\hline 大地の星 & $-0.7 \pm 0.4$ & $-3.8 \pm 0.4$ & $2.8 \pm 0.4$ & $1.4 \pm 0.4$ \\
\hline ゆめぴりか & $0.6 \pm 0.3$ & $-2.1 \pm 0.4$ & $2.4 \pm 0.3$ & $0.6 \pm 0.3$ \\
\hline ほしのゆめ & $-0.1 \pm 0.2$ & $-4.0 \pm 0.3$ & $1.0 \pm 0.2$ & $-0.4 \pm 0.2$ \\
\hline おぼろづき & $1.5 \pm 0.4$ & $-2.5 \pm 0.4$ & $1.9 \pm 0.4$ & $1.2 \pm 0.4$ \\
\hline ななつぼし & $-0.3 \pm 0.2$ & $-2.7 \pm 0.3$ & $1.2 \pm 0.2$ & $-0.1 \pm 0.2$ \\
\hline きらら 397 & $0.7 \pm 0.2$ & $-2.6 \pm 0.2$ & $2.6 \pm 0.2$ & $1.7 \pm 0.2$ \\
\hline ふっくりんこ & $-1.0 \pm 1.0$ & $-4.7 \pm 0.4$ & $-0.6 \pm 1.0$ & $-2.1 \pm 1.0$ \\
\hline
\end{tabular}

り明らかにするため，表 5 で示した推定值の地点ごとの偏 差の平均值と, そのさらに 4 地点平均との差，すなわち, 地点ごとの出穂期推定值の系統誤差の地域間の偏差を表 6 に示す。表 6 より, 他地点と比較して北斗市では出穂が 1.4 〜 2.8 日遅く推定され，札幌市では $0 \sim 1.5$ 日遅く, 比布 町では「大地の星」の出穂は 0.7 日早めに推定されるものの, それ以外の品種は $0.1 \sim 1.1$ 日遅めに推定され，岩見沢市 では逆に $2.3 \sim 3.7$ 日早めに推定されるなど，図 3 の傾向 が他品種にも当てはまること，すなわち地域に依存する発 育モデルの推定值の系統誤差は, 品種に関わらず普遍的な 現象であることが示された。

パラメータ作成に用いるデータの取得先が，大きな系統 誤差を生じさせる地点に偏っている場合, そのデータに最 適化して作成されたモデルは，他地点における発育予測に 大きな誤差を生じることになる。今回取り扱った品種の中 で，「ふっくりんこ」は出穂期が遅いため道南向けの品種 として位置付けられ，定期作況調査データの調査地点は北 斗市のみである。「ふっくりんこ」の発育モデルのパラメー 夕作成には，北斗市でのデータ 15 個に加え，札幌市と石 垣市のデータがそれぞれ 6 個と 2 個，用られているもの の（表 1), 上述の通り北斗市では他地域と比較して出穂 が $1.4 \sim 2.8$ 日遅く，札幌市で $0 \sim 1.5$ 日遅く推定される ため，これらのデータに基づき作成したパラメータでは， 他地域の出穂をより早く推定することになる。なお石垣島 では実測より平均で 2 日早く推定されるが (デー夕省略), デー夕数が 2 個と少ないため影響は小さいと考える。一方 で「きらら 397」は定期作況調査が北斗市，岩見沢市，比 布町で行われており，「ふっくりんこ」に比べると広範な 地域に対してパラメータが最適化されている。これが出穂 期の予測で「きらら 397」と「ふっくりんこ」に逆転を生 じた原因であろう。

発育予測モデルによる推定結果に地域に依存した系統䛊 差を生じる原因は, 発育予測式で考慮されていない気象要 素，および気象以外の要因が水稲の発育に影響しているた めと考える。一般に，水稲の発育には気温以外にも日長が 影響し, そのため緯度の異なる地域間で品種の早晚性が入 れ替わることもあるが (鳥山ら, 1969), 北海道の水稲品 種は日長感応性が無い，もしくは極めて低い（細井, 1981; Ichitani et al., 1997）ため，上述の地域に依存した系統誤差 は日長感応性に起因するものではなく, 気温・日長以外の

表 6. 調査地点ごとの出穂期推定値の系統誤差の地域間差.

\begin{tabular}{ccccc}
\hline \multirow{2}{*}{ 品種 } & \multicolumn{4}{c}{$\begin{array}{c}\text { 出穂期推定值の偏差平均值の } \\
\text { 4 地点平均值との差 * (日) }\end{array}$} \\
\cline { 2 - 5 } & 比布町 & 岩見沢市 & 北斗市 & 札幌市 \\
\hline 大地の星 & -0.7 & -3.7 & 2.8 & 1.5 \\
ゆめびりか & 0.2 & -2.5 & 2.1 & 0.2 \\
ほしのゆめ & 0.8 & -3.1 & 1.9 & 0.5 \\
おぼらづき & 1.0 & -3.0 & 1.4 & 0.7 \\
ななつぼし & 0.2 & -2.3 & 1.7 & 0.4 \\
きらら397 & 0.1 & -3.2 & 2.0 & 1.1 \\
ふっくりんこ & 1.1 & -2.6 & 1.5 & 0.0 \\
\hline
\end{tabular}

* 各地点の出穂期推定值の偏差平均值

- 出穂期推定值の偏差平均值の 4 地点平均值 
要因によって生じていると考えられる。誤差の原因が明ら かであれば，発育予測モデルにてその要因の影響を考慮す るなどにより対処可能であるが，現時点では必ずしも明ら かではない。発育予測に, 地域に依存した系統誤差を生じ ていても, モデル作成データの調査地域と, 発育予測の対 象となる地域が一致していれば問題はない。しかし，想定 される作付け地域が限られる品種の場合, モデルの作成に 利用可能なデータの調査地域が限られることもある一方 で，近年は気候変動・温暖化の影響や，また生産者や需要 側の希望により，品種育成時には想定していなかった地域 への作付け拡大が進んでいる。例えば今回示した「ふっく りんこ」は早晚性が「やや晚」であり, 栽培地域は道南と されていたが, 温暖化に伴い栽培対象地域がそれ以外の地 域にも拡大しており, 発育モデル作成データの取得地域と, その利用地域とに乘離が生じている。

発育予測モデルのパラメータ作成に使うデータが広範な 地域で取得されていれば，比較的広域適用性の高いモデル の作成が期待できる。また，品種間の早晚性の違いを適切 に反映したパラメータセットを得るには, 品種間でデータ 取得地域とデータ数が同じであることが望ましい。今回提 案した方法は, 「基準品種」のデー夕を使い, 他品種のデー 夕を補完することで，これらの条件を満たすデータセット を作出できる。この方法により，データの取得地域が限ら れた品種でも広域適用性を確保し，かつ，新規導入品種な どデー夕数が少ない品種でも信頼性の高い発育予測モデル のパラメータ作成が期待できる。

なお，品種間の早晚の違いを反映する出穂期予測法とし ては補完方式以外にも,「きらら 397」の出穂期予測值か ら図 2 の線形回帰式により各品種の出穂期を推定する方法 が考えられるが，今回作成した生育予測モデルの利用目的 の一つに不稔歩合予測があり，前歴期，危険期，開花期 の推定にDVI值を用いるため, 幼穂形成期や出穂期の日 付だけではなく生育途中の DVI 值が必要であることから, 品種ごとの発育予測モデルの作成を行なった。参考として, 上記「きらら 397」の出穂期推定日からの線形回帰による 方法で求めた出穂期の推定誤差 (RMSE) は9 品種平均で 2.9 日であり，従来方式および補完方式とほとんど変わらず， 一方，同方法による品種間の出穂期の早晚の評価において は，補完方式でみられた「きらら 397」に対して他品種の 出穂を若干早めに推定する傾向（表 4) は見られなかった。 補完方式でみられる「きらら 397」に対して他品種の出穂 を若干早めに推定する傾向については，今後その原因と補 正についての検討が必要であろう。

一方，補完方式によって作成したパラメータでは，必 ずしも出穂期の推定精度は向上しなかった（表 2)。これ は，デー夕補完方式では，地域に依存する系統誤差の原因 そのものに対応し, 誤差を解消しているのではなく, 広範 な地域のデー夕を用いることで, 複数の地域に対応したパ ラメータを求めているためであろう。例えば，表 2 では, 「きたあおば」の推定誤差が補完方式で増大しているが, 「きたあおば」は検証用のデー夕の調査地点が札幌のみで あり，パラメータ作成だけでなく検証用のデータも調査地 点が偏っており, データの個数も少ないことから, 逆にデー 夕補完により他地点にも合うパラメータとしたことで誤差
表 7. 補完方式によって作成した各品種の発育予測モデルパラ メー夕。

\begin{tabular}{|c|c|c|c|c|c|c|c|}
\hline & \multicolumn{4}{|c|}{$\begin{array}{c}\text { 移植日 } \\
\text { ～幼穂形成期 }\end{array}$} & \multicolumn{3}{|c|}{$\begin{array}{c}\text { 幼穂形成期 } \\
\text { ～出穗期 }\end{array}$} \\
\hline & $A_{1}$ & $T h_{1}$ & $G_{1}$ & $B$ & $A_{2}$ & $T h_{2}$ & $G_{2}$ \\
\hline 大地の星 & 0.283 & 16.81 & 21.95 & 0.089 & 0.248 & 17.21 & 17.02 \\
\hline ゆめぴりか & 0.263 & 18.93 & 17.42 & 0.072 & 0.235 & 17.21 & 17.77 \\
\hline ほしのゆめ & 0.235 & 18.24 & 18.60 & 0.055 & 0.172 & 17.67 & 16.38 \\
\hline おぼろづき & 0.253 & 17.33 & 22.57 & 0.079 & 0.218 & 16.86 & 18.42 \\
\hline ななつぼし & 0.250 & 17.37 & 22.50 & 0.079 & 0.208 & 16.67 & 18.63 \\
\hline きらら 397 & 0.264 & 17.58 & 21.83 & 0.055 & 0.195 & 17.71 & 16.27 \\
\hline きたあおば & 0.261 & 17.11 & 22.81 & 0.071 & 0.172 & 18.14 & 16.90 \\
\hline ふっくりんこ & 0.329 & 16.12 & 28.00 & 0.064 & 0.272 & 16.22 & 20.13 \\
\hline たちじょうぶ & 0.264 & 16.53 & 26.17 & 0.051 & 0.244 & 16.28 & 21.80 \\
\hline
\end{tabular}

が増大したと考える。

補完方式の実施には，適切な「基準品種」の設定が不可 欠である。新しい品種の育成の際，および定期作況調査等 では，「標準品種」のデータが取得されている。「きらら 397」は北海道の前標準品種として道内の広範な地域で栽 培され，かつ，データの蓄積も多いことから，補完方式の 基準品種として有効に活用でき，今回それ自身を含め，9 品種の発育予測モデルのパラメータセットを得た（表 7）。 さらに，新しく育成された品種の発育デー夕は近年の温 暖化の影響により，かつてより温度の高い条件下で得られ たものとなっているが，「きらら 397」は北海道において 顕著な気温上昇（札幌管区気象台, 2017; 広田ら, 2017）が 見られる以前の 1980 年代からのデータが蓄積されており, それに基づき新しい品種のデータを補完することで，新し い品種についての発育予測モデルの適用温度域も広がるで あろう。

水稲の新たな品種の育成は続いており，また気候変動に 伴う作付け地域の拡大・移動は今後も続くと予想される。 さらに, 今後の担い手の減少, 経営面積の拡大に伴い, 作 業競合回避を目的に 1 経営体での早晚性の異なる複数品種 の導入も進むであろう。栽培管理の適正化および効率化を 支援する発育予測モデルの構築に，この手法の活用が期待 される。

\section{5. まとめ}

北海道の主要な水稲品種について，気温を用いた DVI 発育予測式のパラメータセットを作成した。発育予測モデ ルのパラメータ作成に利用する発育データについて，品種 による調査地点の偏りやデー夕数，年度の違いがあるまま でパラメータを作成すると，そのパラメータによる出穂期 の推定結果は, 品種の早晚の順位を必ずしも反映しない, という問題を生じた。品種間のデータの調査地点やデー夕 数，年度を揃えるため, 次の方法を提案した。すなわち, 現在の主要品種で最も広範な地域で，かつ長期間のデー夕 が得られている「きらら 397」を基準品種とし，発育予測 モデル作成の対象となる品種では調査されていない地点・ 年度のデータを，その品種と基準品種との発育ステージ (幼穂形成期，出穂期）の線形回帰式に基ついて基準品種 のデータから推定・補完する方法である。この補完方式に より補完されたデータを用いて作成されたモデルパラメー 
夕に基づく発育予測の結果（出穂期の推定值）は，品種間 の早晚の順位をより適切に再現した。

\section{謝辞}

本研究の一部は，総合科学技術・イノベーション会議の SIP（戦略的イノベーション創造プログラム）「次世代農林 水産業創造技術（管理法人：農研機構生物系特定産業技術 研究支援センター)」の支援を受けて行った。また，本研 究の一部は JSPS 科研費 JP25750119 の助成を受けたもので ある。

\section{引用文献}

de Wit CT, Brouwer R, Penning de Vries FWT, 1970: The simulation of photosynthetic systems. Proceedings of International Biological Program/Plant Production Technical Meeting, 47-70.

広田知良・濱菩孝弘, 2015 : 気候变動に対応した水稲作付 け指標改定の考え方. 北海道の農業気象 67, 49-56.

広田知良・山﨑太地 - 安井美裕 - 古川準三 . 丹羽勝久 根本 学 ·濱菩孝弘 ·下田星児 · 菅野洋光 · 西尾善太, 2017: 気候変動による北海道におけるワイン産地の確立 - 1998 年以降のピノ・ノワールへの正の影響一. 生物と 気象 17, 34-35.

堀江 武・ 中川博視, 1990: イネの発育過程のモデル化と 予測に関する研究 第 1 報 モデルの基本構造とパラメー 夕の推定法および出穂予測への適用. 日本作物学会紀事 59, 687-695.

Horie T, Nakagawa H, Ohnishi M, Nakano J, 1995: Rice production in Japan under current and future climates. In Modeling the impact of climate change on rice in Asia (ed. By Martthews RB et al.). CAB Intermational, Oxford, U.K., 143-164.

細井徳夫, 1981: 気象要因による水稲生育の変動性に関す る研究, V. 日本の主要水稲品種の感温性, 感光性, 基本栄 養生長性と出穂日数の制御要因の地域的特徵. 育種学雑 誌 31, 239-250.

Ichitani K, Okumoto Y, Tanisaka T, 1997: Photoperiod sensitivity gene of Se-1 locus found in photoperiod insensitive rice cultivars of the northern limit region of rice cultivation. Breeding Science 47, 145-152.

Iizumi T, Hayashi Y, Kimura F, 2007: Influence on rice production in Japan from cool and hot summers after global warming. Journal of Agricultural Meteorology 63, 11-23.

神田英司, 2007: 東北地方に㧍ける水稲冷害の早期警戒シ ステムの開発に関する研究. 東北農業研究センター研究 報告 107, 71-117.
気象庁, 2018: 気象観測統計の解説.

https://www.data.jma.go.jp/obd/stats/data/kaisetu/index.html (アクセス日 : 2018/10/18)

小林和彦, 1981: シンプレックス法により多変数関数の最 小值を求めるためのサブルーチン. 農林水産研究計算セ ンター報告, A シリーズ 17, 51-71.

森田弘彦・村上利男, 1981: 寒地水稲の計画作期について 第 3 報簡易積算有効気温による作期の計画化. 日本作物 学会紀事 50, 別号 1,1-2.

村上利男 - 森田弘彦 - 土井康生 - 今野一男, 1982: 寒地水 稲の計画栽培に関する解析的研究. 北海道農業試験場研 究報告 133, 61-100.

長田 亨・五十嵐俊成・吉田慎一, 2013: ブランド米生産 に向けた「ゆめぴりか」の栽培指針. 北農 80,2-9.

中川博視・堀江 武, 1995: イネの発育過程のモデル化と 予測に関する研究 第 2 報 幼穂の分化・発達過程の気象 的予測モデル. 日本作物学会紀事 64, 33-42.

中野聡史 · 熊谷悦史 - 島田信二 · 鮫島良次 · 大野宏之 ·本 間香貴・白岩立彦, 2015: ダイズ品種の発育モデルの作 成と気温上昇が発育速度に及ぼす影響の広域推定. 日本 作物学会紀事 84, 408-417.

Nelder JA, Mead R, 1965: A simplex method for function minimization. The Computer Journal. 7, 308-313.

Nemoto M, Hamasaki T, Matsuba S, Hayashi S, Yanagihara S, 2016: Estimation of Rice Yield Components with Meteorological Elements Divided According to Developmental Stages. Journal of Agricultural Meteorology 72, 128-141.

大野宏之・佐々木華織・大原源二 ・ 中園 江, 2016: 実況 值と数值予報, 平年值を組み合わせたメッシュ気温・降 水量デー夕の作成. 生物と気象 16, 71-79.

札幌管区気象台, 2017: 北海道の気候変化【第 2 版】これま での 120 年とこれからの予測. 札幌管区気象台. $37 \mathrm{pp}$.

竹川昌和, 1991: 気象条件から求めた地带別水稲品種選定 の基準 -とくにアメダスゾーンメッシュについてー. 北 海道立農業試験場集報 63, 41-52.

田中英彦, 2007: 気象データに基づく予測システムと活用 (1)作物生育予測 1. 水稲. 畑で読む北海道の農業気象（水 島俊一監修). 北海道協同組合通信社, 札幌市, pp.182-185. 田中英彦, 2016: 北海道における水稲の冷害とその対策. 北 海道の農業気象 68, 17-20.

丹野 久. 田中英彦 ·古原 洋 - 佐々木亮 - 三浦 周, 2007: 寒地水稲の湛水土中直播栽培における簡易有効積 算気温による品種選定. 日本作物学会紀事 76, 591-599.

鳥山国士 ·坂本 敏・岩下友記・徐 進生, 1969: 異なる 緯度で栽培した日本稲の出穂性について. 中国農業試験 場報告 A 17, 1-16. 